\title{
Investment in Public Sector Housing in Nigeria: An Empirical Analysis
}

\author{
MOEMEKE SCHOLASTICA EKENE ${ }^{1}$ AKINPELUMI OMOTAYO FRANKLIN ${ }^{2}$ \\ 1.DEPARTMENT OF BANKING AND FINANACE, SCHOOL OF BUSINESS STUDIES, DELTA STATE \\ POLYTECHNIC, OGWASHI-UKU, DELTA STATE, NIGERIA. \\ 2.DEPARTMENT OF FINANCE AND BANKING, FACULTY OF MANAGEMENT SCIENCES, \\ UNIVERSITY OF PORT HARCOURT, RIVERS STATE, NIGERIA.
}

\begin{abstract}
ABSTARCT
This study evaluated the influence of government expenditure on Housing project development in Nigeria, over the period of 1980 to 2016 while utilizing secondary sourced data culled from the central bank of Nigeria Statistical Bulletin. The study utilized analytical techniques such as Unit root/stationarity test, ordinary least square, cointegration test and granger causality as well as graphical representation. It was discovered that Government Recurrent Expenditure (GRE) has a positive and significant relationship with Housing Development proxied as Housing Stock (HOS), Government Capital Expenditure (GCE) has a positive and significant relationship with Housing Development in Nigeria proxied as Housing Stock (HOS), and Overall, judging by the calculated Fstatistics, it can be concluded that Government expenditure has a significant impact on Housing Development in Nigeria especially in the short run, it was thus recommended that Government should increase their expenditure on projects that will enhance Housing Development; Government should channel their expenditure to productive sectors of the economy in order to increase Housing Development; Necessary enabling legislations should be enacted and incentives given to institutions that are financing housing projects in Nigeria so as to encourage them to be more aggressive in mobilizing idle resources from the public via the money and capital market. Also, Federal Mortgage Bank of Nigeria (FMBN) which is the apex mortgage institution in the country should be reorganized and empowered to ensure proper capitalization and improved service delivery, given its mandate as a regulatory body and the significant influence it has on housing development in Nigeria.
\end{abstract}

Keywords: Housing development, Government Expenditure, Mortgage Financing

DOI: $10.7176 / \mathrm{RJFA} / 11-8-16$

Publication date: April $30^{\text {th }} 2020$

\section{INTRODUCTION}

Housing has been identified as the most basic need of mankind for obvious reasons, others being food and clothing. Also, housing is a very important durable consumer item, which impacts positively on productivity, as decent housing significantly increases workers' health and well-being hence, the need for housing development in a country (Ayodele et al, 2013). Developed housing sector is one of the indices for measuring the standard of living of people across societies; thus, necessitating programmes of assistance from the government in the areas of housing financing, provision of infrastructure and research so as to enhance its adequate delivery. Sustainable mortgage finance can go a long way toward breaking the vicious circle of poverty and foster Housing Development and national development (Oyedokum et al., 2013).

Housing finance is composed majorly of loan facilities granted by commercial banks or mortgage banks to finance the purchase of real estate with specific payment schedule and interest charge (Colaniran, 2003 as cited in Okidim and Ellah, 2013). It has been said that Housing financing in Nigeria is necessary for housing sector development. There is no doubt that the nation's mortgage sector has experienced different phases in the last three decades but the sector has remained unpopular among Nigerians because it has failed to play its role of assisting Nigerians desirous of owning their own houses (Okonjo-Iweala, 2013).

In recent years, the banking and economic reforms in the country have had stimulating effects on the mortgage industry. The improved prospects of long-term finance have raised the potential for enhanced housing delivery, home ownership and real estate development through Housing financing strategies. Despite the improved prospects, Nigeria's mortgage industry has remained underdeveloped, as reflected in poor housing development and Housing finance indicators. Underdeveloped mortgage industry in Nigeria is underscored by the fact that mortgage loans amounted to only 0.12 percent of Gross Domestic Product (GDP) in 2006, compared to 3 percent in Ghana and 5 percent in India. So far, this statistics has not changed much. Recent revelations by the CBN Deputy Governor (financial system stability), exposed the realistic grim state of the Housing finance/(GDP) relationship in Nigeria as compared to other countries. He pointed out that in Malaysia it accounts for 24.7 percent of GDP; 29 percent in South Africa; and 85 percent in New Zealand, (Thisday News paper September, 2011). However, it may be noted that most of these countries enjoy an average income that is higher than that of the average Nigerian.

Attaining Housing Development and Development has been a major goal pursued by most countries, a key 
phenomenon to Housing Development as explained by Ezebasily and Nwakoby (2013) as the pivotal role of the Public sector in initiating, managing and financing this proposed growth and development.

In almost all economies today, government intervenes in undertaking fundamental roles of allocation, stabilization, distribution and regulation especially where or when market proves inefficient or its outcome is socially unacceptable. Also, governments particularly in developing economies intervene to achieve macroeconomic objectives such as Housing Development and development, full employment, price stability and poverty reduction (Usman et al 2011), which brings us to government expenditure. Government spending (or government expenditure) includes all government consumptions and investments but excludes transfer payments made by a state. Government expenditure can be for the acquisition of goods and services for current use to directly satisfy individual or collective needs of the members of the community or it can be for acquisition of goods and services intended to create future benefits such as infrastructure investment and the expenditures can represent transfers of money, such as social salaries and cost of administration (Modebe et al , 2012).

In line with Chinweoke (2014), Government expenditure could be broadly classified into recurrent expenditure and capital expenditure. The expenditures of government which occur regularly throughout the year are referred to as recurrent expenditures. They must be made regularly if the functions of government must be maintained. They include regular salaries of all employees, money spent on the running of essential services or regular maintenance of infrastructural facilities and money spent on the administration of the State. Capital expenditures on the other hand are the expenditures of government on the acquisition of things of permanent nature (Nwaeze 2010). They include all expenditures on capital projects such as buildings, construction of roads, bridges and all permanent structures and assets. These usually involve large sums of money and also form the basis of the physical development of a nation.

However, according to Paternostro et al (2007), there is no consensus on the theoretical literature as to the impact of public expenditure on housing development. A handful of empirical studies support the theoretical view that healthy budgetary balances or consistent budget surpluses are required for Housing Development in the long run (Easterly et al, 1984). However, the effect of fiscal consolidation on growth in the short run remains questionable. Studies by McDermott and Wescott, (1996); Alesina and Perotti, (1996); Butti and Sapir, (1998); Alesina et al, (2002); and Von Hagen and Strauch, (2001), concentrating on industrial countries have concluded that under certain circumstances, fiscal contraction can stimulate Housing Development. These studies were centered on the belief that the composition of fiscal adjustments plays a major role in the determination of whether fiscal contractions lead to sustainable Housing Development or not (Onyemaechi, 2014). These studies are also of the opinion that improvement in Government expenditure composition or components through rationalisation of government wage bills and public transfers, instead of increase in tax revenues and reduction in public investments, can stimulate growth even in the short run and majority have overlooked the role of deficit financing amidst the expenditure realm.

This study therefore seeks to re-examine the issue of Government Expenditure with a cursory look at the level of its activities in housing development in a developing nation such as Nigeria.

\section{Statement of the Problem}

There is no doubt that one of the foremost challenges of the Nigerian economy is that of developing a sustainable housing and Housing finance system which befits a dynamic, competitive economic \& financial system such as Nigeria's. It has been discovered that Nigeria had a housing deficit which would require a huge amount of funds in addition to having to produce a minimum of 720,000 housing units annually for the next 20 years in order to close the housing gap in the Country. Available statistics show that since inception in 1973 up to 2006, the various Federal Government Housing Agencies had not been able to build enough housing units to considerably close and reduce the seeming deficit (Omotoso, 2011).

In Nigeria, the housing problem can best be described as endemic. From the $1970^{\circ e}$ s crude oil began to play a major role in the growth of the economy, resulting in extensive urban migration and worsening housing problem. This challenge requires attention from both the public and private sector. Despite the Federal government's access to factors that can engender housing development, only about 4.0 percent of annual housing requirements are met. Available statistics from the national bureau of statistics (NBS) indicates that 80.0 percent of Nigeria's population housing requirements are met through private sector efforts, while governments at the three-tier levels provide the remaining 20.0 percent (NBS, 2013).

\section{Objectives of the study}

This study primarily aims to examine and evaluate the impact of Government Expenditure on Housing Development in Nigeria while the specific objectives include:

i. To determine the impact of Government Recurrent Expenditure on Housing Stock in Nigeria.

ii. To examine the impact of Government Capital Expenditure on Housing Stock in Nigeria.

iii. To empirically examine the impact of Deficit Financing on Housing Stock in Nigeria.

\section{Research Questions}

In line with the above objectives, the following questions become pertinent: 
i. To what extent does Government Recurrent Expenditure influence Housing Stock in Nigeria?

ii. To what extent does Government Capital Expenditure influence Housing Stock in Nigeria?

iii. To what extent does Deficit Financing influence Housing Stock in Nigeria?

\section{Research Hypotheses}

In line with the study objective and research questions, the following null hypotheses $\left(\mathbf{H}_{\mathbf{0}}\right)$ were formulated:

Ho1: There is no significant relationship between Government Recurrent Expenditure and Housing Stock in Nigeria.

Ho2: There is no significant relationship between Government Capital Expenditure and Housing Stock in Nigeria.

Ho3: There is no significant relationship between Deficit Financing and Housing Stock in Nigeria.

Significance of the Study

For Practitioners, this study will be essential for policy makers to know more about the performance of the employed Deficit Financial Fiscal Expenditure activities in the nation and its growth effect on the economy. For Scholars, This study would provide the basis/frame work for further research in this area of study as well as foreign policy development and implementation which will enhance precision in Government Expenditure, World Fiscal policy treaties/debates to facilitate easy assessment of loop holes, mistakes and shortcomings to enable relevant and timely decisions to forestall future occurrences.

\section{Scope of the Study}

This study is focused on the role of Government Expenditure on Housing development, Spanning over a period of 1980 to 2016 while focusing on Fiscal and Growth theories. It also falls within the geographical boundary of the Nigerian Economy at the international level and contains all Government Expenditure activities and transactions within the economy.

This study intends to investigate the national Government Expenditure activities in Nigeria and how they influence national Housing Development.

\section{REVIEW OF RELATED LITERATURE}

\subsection{Theoretical Framework:}

This section clarifies related theories underpinning Government Expenditure and Housing Development in Nigeria. Since Government Expenditure has its roots in fiscal policy they are thus predicated on the following schools of thought:

\subsubsection{Theory of Increasing Public Expenditure}

There are two important and well-known theories of increasing public expenditure. The first one is connected with Wagner and the other with Wiseman and Peacock. On the one hand, Wagner revealed that there are inherent tendencies for the activities of different layers of a government (such as central, state and local governments) to increase both intensively and extensively. He maintained that there was a functional relationship between the growth of an economy and government activities with the result that the government sector grows faster than the economy. However Nitti (1903) not only supported Wagner's thesis but also concluded with empirical evidence that it was equally applicable to several other governments which differed widely from each-other (Nitti, 1903). All kinds of governments, irrespective of their levels (say, the central or state government), intentions (peaceful or warlike), and size had exhibited the same tendency of increasing public expenditure. But on the other hand, Wiseman and Peacock in their study of public expenditure in UK for the period 1890-1955 revealed that public expenditure does not increase in a smooth and continuous manner, but in jerks or steps like fashion. At times, some social or other disturbance takes place creating a need for increased public expenditure which the existing public revenue cannot meet.

\subsubsection{The Title Theory}

The basic concept of the Title theory as stated by Gilbert (1968) is that upon making the mortgage, the mortgagor passes title of the property, the subject of the mortgage, to the mortgagee, subject to a condition subsequent. This condition subsequent is the payment of the debt. Upon fulfilment of the condition, title to property divests (reverts to) the mortgagor. For example, A (mortgagor) mortgages real property to B (the mortgagee) in a title state. Under the terms of the instrument, title passes on to B. however, the instrument will state that if A complies with the condition (makes payment), then the instrument will be void. At the time of the mortgage, by virtue of a provision in the mortgage, A is generally entitled to remain in possession of the property even though he passed title to his mortgagee (Olumide et al, 2013).

\subsubsection{The Lien Theory}

The lien theory on the other hand which is adopted by majority of the countries was developed by Hester (1975) and it allows title to remain with the mortgagor and the mortgage that is placed on the property is a charge on the title. The mortgage instrument says nothing about title, but state "The mortgagor does hereby mortgages to the mortgagee". After the recording of the instrument, it becomes a lien on the property described in the mortgage. The rule regarding the priority of mortgages whether in title or lien states is substantially the same rule as that regarding the priority of deeds the instrument recorded first, in the absence of fraud, is the operative one. To avoid 
such circumstances, mortgages should be recorded immediately. It is from the idea of having the first lien against the property that the term "first mortgage" was derived. The term "first mortgage" simply means that the party holding such instrument has recorded mortgage first in point of time and thus has priority over any subsequently recorded mortgages. First mortgage, Second mortgage, third mortgage, and so on as stated by Dobson (1976) indicates the order of their recording, and by the same token, the priority in case of foreclosure for the private creditors (Olumide et al, 2013).

\subsubsection{Ernest Engel's Theory of Public Expenditure}

Ernest Engel was also a German economist writing almost the same time as Adolph Wagner in the $19^{\text {th }}$ century. Engel pointed out over a century ago that the composition of the consumer budget changes as family income increases. A smaller share comes to be spent on certain goods such as work clothing and a larger share on others, such as for coats, expensive jewelries etc.

As average income increase, smaller charges in the consumption pattern for the economy may occur. At the earlier stages of national development, there is need for overhead capital such as roads, harbors, power installations, pipe-borne water etc. But as the economy developed, one would expect the public share in capital formation to decline over time. Individual expenditure pattern is thus compared to national expenditure and Engel's finding is referred to as the declining portion of outlays on foods (Muritala and Abayomi, 2011).

\subsection{Empirical Literature}

Oyedokun, Adewusi, Oletubo and Thomas (2013) used questionnaire, weighted mean score and rank correlation analysis to investigate the mortgage lending in Nigeria. It was discovered that statistical based credit models are seldom used by the lenders while the evolving role of information technology in mortgage lending is yet to be given due attention. Ozurumba (2011) in a related study, examined the urban housing financing in the SouthEastern states of Nigeria using correlation analysis. It was revealed that inefficient machinery and inadequate funding for effective implementation of the nation's housing program is caused by the operation of the mortgage banks in Nigeria.

The literature on housing delivery in Nigeria is one that has received a sizeable attention for some time. The housing delivery system in Nigeria is a mix of many interrelated components which include, land, infrastructure building materials, policies, building regulations and importantly the Finance component of it. Scholars such as Adebamowo et al. (2012);

Williams (2002) opines that access to housing produced by the government is still out of the reach of the urban poor who simply cannot afford the financial resources needed to purchase these housing units. This calls to question the success or otherwise of the National Housing Fund (NHF) which has been the bedrock of government's housing policy.

Ogu and Ogbuozobe (2001) argue for the creation of an enabling environment, including support of housing initiatives and investments by householders, small-scale providers, and entrepreneurial private firms. Their study also identify the implications of having an enabling strategy for housing finance, access to land, residential infrastructure, institutional regulations and building materials and related industry mostly in the light of the need for the private sector to play greater roles in housing.

Onyemaechi (2014) evaluated the expenditure component of fiscal policy on Economic Growth in Nigeria over a period of 1981 to 20013 by examining the characteristics of the relevant time-series using the unit root tests of stationary and co-integration tests. Positive impact of federal expenditure on administration, as well as social and community services on economic growth was discovered.

Baghebo and Edoumiekumo (2012) used the disaggregated approach to examine the relationship between public capital accumulation and economic development in Nigeria covering the period $1970-2010$. The stationary status of the time series data was determined using group Unit root test. The variables attain stationarity after first difference. The long run equilibrium relationship among the variables in the model was examined using Johanson co integration rank test of trace and maximum engen value test. The short run dynamic adjustments required for stable long run equilibrium relationship among the variables was estimated using the Error correction mechanism. The result revealed that an insignificant positive relationship exist between capital expenditures and economic development in Nigeria.

Oni et al (2014) investigates the joint effects of capital and recurrent expenditures of government on the economic growth of Nigeria using the ordinary least square method for estimating multiple regression models covering 1980-2011 time period. The regression results showed that both capital and recurrent expenditures impacted positively on economic growth during the period of study.

\section{RESEARCH METHODOLOGY}

\section{Research Design}

For the Purpose of this study, the Ex-post Factor Research Design also known as the Investigative econometric research design is utilized as it represents a non-experimental design in which pre-existing groups are compared 
with some dependent variables.

Population and Sampling Procedure

The population of this study consists of all economic variables associated with Government expenditure and Housing Development activities in Nigeria out of which a set of variables were selected which includes Capital Expenditure and Recurrent Expenditure for the Government Expenditure variables, while Housing Development was denoted by Housing Stock over the time period of 1980 to 2016.

\section{Method of Data Collection}

Secondary sourced data were utilized for this study. These data were time series and cross sectional. The data reflected the Gross Domestic Product, spanning from 1980 to 2016. The data were sourced and extracted from existing documents and materials. These include the Central Bank of Nigeria (CBN) statistical Bulletin, CBN Annual Report and Statement of Account, CBN Bullion, text books, journals and internet sources.

\section{Model Estimation}

The model follows the classical linear regression model (CLRM) and is stated as follows:

$\mathrm{HOS}_{\mathrm{t}}=f\left(\mathrm{GRCE}_{\mathrm{t}}, \mathrm{GCCE}\right)$

Converted to the mathematical/econometric form by the introduction of the $(\alpha 0)$ and error term $(\mu)$ :

$\mathrm{HOS}_{\mathrm{t}}=\alpha_{0}+\alpha_{1} \mathrm{GRCE}_{\mathrm{t}}+\alpha_{2} \mathrm{GCCE}_{\mathrm{t}}+\mu-----------------(3.2)$

Where:

HOS $=$ Housing Stock

GRCE $=$ Government Recurrent Expenditure

GCCE $=\quad$ Government Capital Expenditure

$\alpha_{0} \quad=\quad$ Constant Term

$\alpha_{1}-\alpha_{2}=\quad$ Coefficients of Predictors

\section{Apriori Expectation}

Based on theories and empirical studies, the predictor variables have varying relationship with the dependent criterion variables which is therefore mathematically states as:

$\alpha 1$, and $\alpha 2>0$.

This signifies a positive relationship amongst the Predictor variables and the criterion variable. I.e. as one is increasing, the other is increasing and as one decreases, the other decreases as well.

Operational Measures of Variables

Dependent Variable

Housing Stock (HOS): This is captured by the available housing stock in Nigeria over the study period.

Explanatory or Independent Variable

Government Recurrent Expenditure (GRCE): This is captured as all payments other than for capital assets, including on goods and services, (wages and salaries, employer contributions), interest payments, subsidies and transfers measured in billions, a positive theoretical relationship is expected with the dependent variable (GDP)

Government Capital Expenditure (GCCE): This is captured as expenditure on physical and long term assets such as roads, bridges, hospital buildings and equipment, measured in billions of naira, a positive theoretical relationship is expected with the dependent variable (GDP)

Model Estimation Techniques:

To investigate the nature of the volatility of the interest rate and intervening variables on Economic Performance, the following tools have to be utilized.

Stationarity Tests:

The stationarity of series is necessary to evaluate unit root attributes of the time series. Accordingly, the Augmented Dickey Fuller (ADF) test is employed. The decision is to reject the null hypotheses if the ADF test statistics is absolutely higher than the Mackinnons Critical Values at $1 \%, 5 \%$ and $10 \%$ levels of significance (Brooks, 2009).

Generalized autoregressive conditional heteroscedasticity (GARCH): This is a Process is an econometric term established in 1982 by Robert F. Engle: It is usually modeled as follows:

$\operatorname{Var}(y t \mid y t-1, \ldots, y t-m)=\sigma 2 t=\alpha 0+\alpha 1 y 2 t-1+\cdots+\alpha m y 2 t-m$.

Decision Rule: $y_{t}$ is white noise when $0 \leq \alpha_{1} \leq 1$.

Impulse Response: refers to the response of any dynamic system in response to some external changes. In both cases, the impulse response describes the reaction of the system as a function of time.

$\mathrm{y}_{\mathrm{t}}=\mathrm{y}^{\mathrm{s}}+\mathrm{Ay}_{\mathrm{t}-1}^{\mathrm{h}}+\mathrm{Bu}_{\mathrm{t}}$

Variance Decomposition: The variance decomposition designates the amount of information each variable contributes to the other variables in the autoregression. It determines how much of the forecast error variance of each of the variables can be explained by exogenous shocks to the other variables. It is usually modeled as follows: $\mathrm{y}_{\mathrm{t}}=\mathrm{v}+\mathrm{A}_{1} \mathrm{y}_{\mathrm{t}-1}+\ldots+\mathrm{A}_{\mathrm{p}} \mathrm{y}_{\mathrm{t}-\mathrm{p}}+\mathrm{u}_{\mathrm{t}}$ 


\section{DATA PRESENTATION AND ANALYSIS}

Data Presentation

The statistical data utilized for this study was collected from Central Bank of Nigeria (CBN) statistical bulletin of 2016. It will present both the dependent and independent variables as related to the study.

Table 1: Housing Stock (HOS), Government Capital Expenditure (GCCE), Government Recurrent Expenditure (GRCE): 1980 - 2016.

\begin{tabular}{|c|c|c|c|}
\hline Year & HOS ('000) & GRCE (N'Billion) & GCCE (N'Billion) \\
\hline 1980 & 8859 & 3.9672 & 6.8435 \\
\hline 1981 & 11779 & 4.8467 & 6.5670 \\
\hline 1982 & 14699 & 5.5060 & 6.4172 \\
\hline 1983 & 17618 & 4.7508 & 4.8857 \\
\hline 1984 & 20538 & 5.8275 & 4.1001 \\
\hline 1985 & 23458 & 7.5764 & 5.4647 \\
\hline 1986 & 26378 & 7.6969 & 8.5268 \\
\hline 1987 & 29297 & 15.6462 & 6.3725 \\
\hline 1988 & 32217 & 19.4094 & 8.3401 \\
\hline 1989 & 35137 & 25.9942 & 15.0341 \\
\hline 1990 & 40331 & 36.2196 & 24.0486 \\
\hline 1991 & 41823 & 38.2435 & 28.3409 \\
\hline 1992 & 43132 & 53.0341 & 39.7633 \\
\hline 1993 & 44880 & 136.7271 & 54.5018 \\
\hline 1994 & 46104 & 89.9749 & 70.9183 \\
\hline 1995 & 53938 & 127.6298 & 121.1383 \\
\hline 1996 & 55804 & 124.2913 & 212.9263 \\
\hline 1997 & 58863 & 158.5635 & 269.6517 \\
\hline 1998 & 62747 & 178.0978 & 309.0156 \\
\hline 1999 & 65647 & 449.6624 & 498.0276 \\
\hline 2000 & 69656 & 461.6000 & 239.4509 \\
\hline 2001 & 76572 & 579.3000 & 438.6965 \\
\hline 2002 & 81628 & 696.8000 & 321.3781 \\
\hline 2003 & 81628 & 984.3000 & 241.6883 \\
\hline 2004 & 86195 & 1032.7000 & 351.3000 \\
\hline 2005 & 89495 & 1223.7000 & 519.5000 \\
\hline 2006 & 90692 & 1290.2019 & 552.3858 \\
\hline 2007 & 93592 & 1589.2700 & 759.3230 \\
\hline 2008 & 95463 & 2117.3620 & 960.8901 \\
\hline 2009 & 97372 & 2127.9715 & 1152.7965 \\
\hline 2010 & 99701 & 3109.3785 & 883.8745 \\
\hline 2011 & 102410 & 3314.5133 & 918.5489 \\
\hline 2012 & 107360 & 3325.1565 & 874.8340 \\
\hline 2013 & 124015 & 3689.0611 & 1108.3864 \\
\hline 2014 & 127621 & 3426.8979 & 783.1224 \\
\hline 2015 & 128242 & 3831.9474 & 818.3650 \\
\hline 2016 & 1229507 & 4178.5936 & 634.8036 \\
\hline
\end{tabular}

Source: CBN Statistical bulletin (2016).

Presentation of Stationarity (Unit Root) Test Results:

The results of the stationarity tests for all the study variables are presented in table 2 below: 
Table 2: Results of Stationarity (Unit Root) test:

\begin{tabular}{|l|c|c|c|c|c|c|}
\hline \multirow{2}{*}{ Variable } & $\begin{array}{c}\text { ADF t- } \\
\text { statistics }\end{array}$ & \multicolumn{3}{|c|}{ Critical Value 5\% } & \multirow{2}{*}{$\begin{array}{c}\text { Order of } \\
\text { Integration }\end{array}$} & Prob. \\
\cline { 3 - 6 } & & $\mathbf{1 \%}$ & $\mathbf{5 \%}$ & $\mathbf{1 0 \%}$ & & \\
\hline D(HOS) & -4.323698 & -3.632900 & -2.948404 & -2.612874 & $\mathrm{I}(1)$ & 0.0016 \\
\hline D(GRCE) & -3.859171 & -3.773277 & -3.557759 & -3.212361 & $\mathrm{I}(1)$ & 0.0060 \\
\hline D(GCCE) & -7.596244 & -3.632900 & -2.948404 & -2.612874 & $\mathrm{I}(1)$ & 0.0000 \\
\hline
\end{tabular}

Source: Author's compilation.

Note: $\mathrm{D}(\mathrm{HOS}), \mathrm{D}(\mathrm{GRCE})$, and $\mathrm{D}(\mathrm{GCCE})$ represent the differenced values of Housing Stock, Government Recurrent and capital expenditure respectively.

Source: Authors Computations using E-Views 9.

From the table above, going by the decision rule above, it could be observed that all variables are stationary at their first difference (1), as the absolute values of their ADF test statistics are all higher than their respective MacKinnon's critical values at $1 \%, 5 \%$ and $10 \%$ respectively.

\subsection{Analysis of Empirical Results}

The regression result shows a viable global status as the predictor variables account for 84.99 percent of variation in the criterion i.e. housing stock which captures housing development.

The above short run output shows that both government expenditure patterns has positive and significant influence on housing development based on their positive coefficient of 1.206874 and 4.724643 and probability level of 0.0022 and 0.0013 for Government recurrent expenditure and government capital expenditure respectively. The fstatistics of coefficient of 98.23113 at a probability level of 0.0000 which is less than the 0.05 significance level shows a viable model. While the Durbin Watson shows the presence of positive serial correlation based on the statistics of 2.22 .

Cointegration Test

Based on the existence of a single cointegrating equation as seen in the Trace and MaximuEigen Value statistics, it can be concluded that there is seen to exist no long run significant relationship which shows that in the presence of changes, the variables are likely not to significantly influence each other.

\section{Granger causality}

The following is the test of causal influence between employed variables, the causality shows that the employed explaining variables which include Government Capital and Recurrent expenditure do not possess bi-directional causal relationship with Housing Development as captured by housing stock in Nigeria as seen over the study period which is evidenced by the probability level which are seen to be greater than the 0.05 significance level. While for unidirectional relationship, Causality ran from HOS i.e. Housing stock to Government recurrent expenditure. Others show no form of causality.
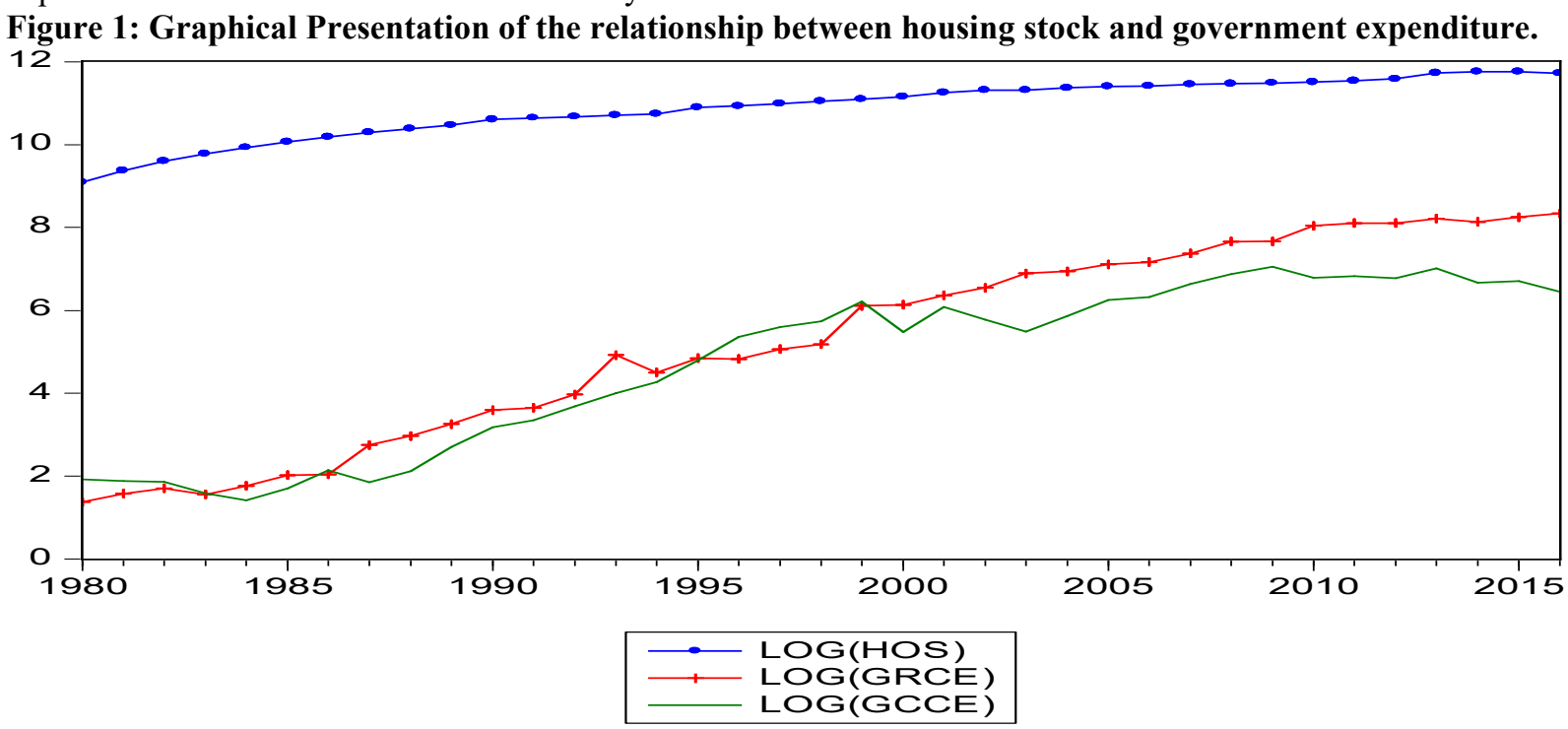

The above graph shows that housing allowance has maintained a steady trajectory than the volatile nature of both government recurrent (GRCE) and capital expenditure (GCCE) as seen over the study period. 


\section{DISCUSSION, CONCLUSION AND RECOMMENDATIONS \\ Discussion of findings}

From the E-Views 9 regression analysis carried out, the computed t- value of the regression coefficient of Government Recurrent Expenditure is 3.305673at a probability level of 0.0022 , which is less than the 5 percent significance level; we reject the null hypothesis and accept its alternate form, which states that there is a statistically significant relationship between Government Recurrent Expenditure and Housing Development in Nigeria proxied by Housing Stock. The computed t- value of the regression coefficient of Government Capital Expenditure is 3.519979 at a probability level of 0.0013 which is greater than the 5 percent significance level; we therefore reject the null hypothesis, concluding that there is statistically significant relationship between Government Capital Expenditure and Housing Development in Nigeria proxied by Housing Stock.

From the forgoing, it can be realized that based on the output above;

- Government Recurrent Expenditure (GRE) has a positive and significant relationship with Housing Development proxied as Housing Stock (HOS),

- Government Capital Expenditure (GCE) has a positive and significant relationship with Housing Development in Nigeria proxied by Housing Stock (HOS),

- Overall, judging by the calculated F-statistics, it can be concluded that Government expenditure has a significant impact on Housing Development in Nigeria.

\section{Conclusion:}

This study focused on the impact government expenditure on Housing Development of Nigeria. The work depended on the publication of Central Bank of Nigeria for necessary data needed to aid computation through the application of Econometric-Views. The output derived was used to test the hypothesis which confirmed that government expenditure on Housing Stock.

Although, the negative total capital expenditure significantly influence the Housing Development in Nigeria, yet the impact of government expenditure on Housing Development is positive and significant.

\section{Recommendations:}

1. Government should channel their expenditure to productive sectors of the economic in order to increase Housing Development.

2. Government should increase their expenditure on projects that will enhance Housing Development.

Necessary enabling legislations should be enacted and incentives be given to institutions that are financing housing in Nigeria so as to encourage them to be more aggressive in mobilizing idle resources from the public via the money and capital market.

3. There should be new regime of Housing finance policy aimed at boosting public confidence in saving and investing in mortgage related instruments, equally in the capital market.

4. The apex mortgage institution (FMBN) should be reorganized and empowered to ensure proper capitalization and improved service delivery. This is because of its significant effect on housing for all in Nigeria.

5. The existing procedure for mortgage lending by commercial banks, mortgage banks and private investors should be reviewed with the aim of making funds for property development accessible to prospective borrowers at cheaper rates.

\section{References}

Abu, N. \& Abdullahi, U (2010). Government Expenditure and Economic Growth in Nigeria, 1970-2008: A Disaggregated Analysis. Business and Economics Journal, 2010: BEJ-4. Retrieved from: http://astonjournals.com/bej (10/18/15).

Alesina, A., and Perotti, R. (1996). Fiscal adjustments in OECD countries: composition and macroeconomic effects. IMF Working Paper No. 96/70.

Alesina, A., Ardagna, S., Perotti, R., Schiantarelli, F. (2002). Fiscal policy, profits, and investment. American Economic Review 92, $571-589$.

Ayodele, O. S, Obafemi, F.N, \& Sabastine,A (2013), Options for Sustainable Housing finance in Nigeria, British Journal of Economics, Finance and Management Sciences, 8(2), 23-48.

Baghebo, M and Edoumiekumo S. (2012). Public capital Accumulation and Economic Development in Nigeria 1970 -2010. International Journal of Academic Research in Business and Social Science (IJARBSC) Vol. 2 (6),213-237. CBN (1996) Statistical facts, Lagos.

Butti, M., and Sapir, A. (1998). Economic policy in EMU. Oxford University Press, Oxford.

CBN Statistical Bulletin, (2016), Annual Report and Statement of Accounts Pp.97-99

Central Bank of Nigeria (2016), Statistical Bulletin, Abuja.

Dewtt, K. K., (2005). Modern Economic theory. Shyam Lal Charitable Trust, New Delhi.

Dobson, S. W. (1976): Development in the capital market in the United States. Business Review, Federal Reserve Bank of Dallas, April 1976.

Easterly, W., and Rebelo, S. (1993). Fiscal policy and economic growth: an empirical investigation. NBER 
Working Paper No. 4499. National Bureau of Economic Research. Cambridge, MA.

EViews 9 User's Guide I, Quantitative Micro Software

Foreign Direct Investment (FDI) Magazine (2003). Foreign direct investment potential to succeed. Retrieved January 14, 2010 from http://www. fdimagazine.com/news/printpage.php.aid/464/Potentialto succeed.html

Gilbert, N.W. (1968): The History, Principles and Practice of Banking. New York Greenwood Press

Hester, D.P. (1995): Bank Management and Portfolio Behaviour. New York: Yale University Press.

McDermott, C.J., and Wescott, R.F. (1996). An empirical analysis of fiscal adjustments. IMF Staff Papers 43 (December), $725-753$.

Modebe, N.J, Regina, .O, \& Onwumere,J.U.J , (2012), Impact of Recurrent and Capital Expenditure on Nigeria's Economic Growth, European Journal of Business and Management www.iiste. ISSN 2222-2839 (Online) Vol 4, No.19, $66-74$.

Muritala, T \& Abayomi, T (2011), Government Expenditure and Economic Development: Empirical Evidence from Nigeria, European Journal of Business and Management, ISSN 2222-2839 (Online)Vol 3, No.9, 18 28.

Nitti, R.O (1903): Public Expenditure and Economic Growth: A Disaggregated Analysis for Developing Countries, JEL, Publication.

Nwaeze, C., (2010). Public Financial Management: Theory and Practice. Reconciliation Publishers Limited, Aba.

Okidim, I.A \& Ella, G.O. (2013), Enhancement of Economic Growth Through Housing financing And Capitalization, Global Journal of Commerce and Management Perspective, 2(5), 8-11.

Okonjo-Iweala, N. (2013), Jonathan to launch new Mortgage Refinancing Company in Nigeria. Daily Independent.

Olumide, S.A, Frances, N.O,\& Akongwale, S. (2013), Options for Sustainable Housing finance in Nigeria, British Journal of Economics, Finance and Management Sciences, 8(2), 23-48.

Omotoso, K (2011). Mortgage Banking/ Housing Finance Sector in Nigeria: Past, Present and Future, Mortgage Banking Association of Nigeria, 1-9.

Onyemaechi,J.O (2014), Impacts Of Fiscal Policy Components On Economic Growth In Nigeria: An Empirical Trend Analysis, Kuwait Section of Arabian Journal of Business and Management Review Vol. 4, No.1;01 19

Oyedokun, T. B., Adewusi, A. O., Oletubo, A. \& Thomas, O. J. (2013), Investigation of Mortgage Lending: An Overview of Nigerian Practice. Research Journal of Finance and Accounting, 4(12): 150-158.

Paternostro, S. (2007), How Does the Composition of Public Spending Matter?, Oxford Development Studies, Vol. 35 , No.1, pp.47- 82

Sanusi, J. (2003). Housing financing in Nigeria: Issues and Challenges; Paper presented at the 9th John Wood Ekpenyong Memorial Lecture, organized by the Nigerian Institute of Estate Surveyors and Valuers, Lagos.

Usman, A ; Mobolaji, H. I; Kilishi, A. A.; Yaru, M. A.; \& Yakubu, T. A. (2011), Government expenditure. Asian Economic and Financial Review, 1(3),pp. 104-113

Von Hagen, J., \& Strauch, R. (2001). Fiscal consolidation: quality, economic conditions, and success. Public Choice $109,327-346$. 